OPEN ACCESS

Edited by:

Eui Bae Jeung

Chungbuk National University,

South Korea

Reviewed by:

Mohammad Abdulkader Akbarsha, National College, Tiruchirappalli, India

Hartmut Jaeschke,

University of Kansas Medical Center

Research Institute, United States

*Correspondence:

Hanry Yu

hyu@ibn.a-star.edu.sg

Florent Ginhoux

florent_ginhoux

@immunol.a-star.edu.ss

Specialty section

This article was submitted to

In Vitro Toxicology,

a section of the journal

Frontiers in Toxicology

Received: 12 September 2020

Accepted: 30 March 2021

Published: 27 April 2021

Citation:

Tasnim F, Huang $X$, Lee CZW, Ginhoux F and Yu H (2021) Recent

Advances in Models of

Immune-Mediated Drug-Induced Liver Injury. Front. Toxicol. 3:605392. doi: 10.3389/ftox.2021.605392

\section{Recent Advances in Models of Immune-Mediated Drug-Induced Liver Injury}

\author{
Farah Tasnim ${ }^{1,2}$, Xiaozhong Huang ${ }^{1,2,3}$, Christopher Zhe Wei Lee ${ }^{1,4,5}$, \\ Florent Ginhoux ${ }^{1,4,5,6,7 *}$ and Hanry $Y u^{1,2,3,8,9,10 *}$
}

${ }^{1}$ Innovations in Food \& Chemical Safety Programme, A*STAR, Singapore, Singapore, ${ }^{2}$ Institute of Bioengineering and Nanotechnology, The Nanos, Singapore, Singapore, ${ }^{3}$ Department of Physiology, Yong Loo Lin School of Medicine, National University of Singapore, Singapore, Singapore, ${ }^{4}$ Singapore Immunology Network, Singapore, Singapore, ${ }^{5}$ School of Biological Sciences, Nanyang Technological University, Singapore, Singapore, ${ }^{6}$ Shanghai Institute of Immunology, Shanghai JiaoTong University School of Medicine, Shanghai, China, ${ }^{7}$ Translational Immunology Institute, SingHealth Duke-NUS Academic Medical Centre, Singapore, Singapore, ${ }^{8}$ National University of Singapore (NUS) Graduate School for Integrative Sciences and Engineering, Centre for Life Sciences, Singapore, Singapore, ${ }^{9} \mathrm{~T}$-Labs, Mechanobiology Institute, Singapore, Singapore, ${ }^{10}$ Critical Analytics for Manufacturing Personalised-Medicine Interdisciplinary Research Groups (CAMP-IRG), Singapore-Massachusetts Institute of Technology Alliance for Research and Technology, Singapore, Singapore

Hepatic inflammation is a key feature of a variety of liver diseases including drug-induced liver injury (DILI), orchestrated by the innate immune response (Kupffer cells, monocytes, neutrophils, dendritic cells) and the adaptive immune system (T cells and natural killer T cells). In contrast to acute DILI, prediction of immune-mediated DILI (im-DILI) has been more challenging due to complex disease pathogenesis, lack of reliable models and limited knowledge of underlying mechanisms. This review summarizes in vivo and in vitro systems that have been used to model im-DILI. In particular, the review focuses on state-of-the-art in vitro human-based multicellular models which have been developed to supplement the use of in vivo models due to interspecies variation and increasing ethical concerns regarding animal use. Advantages of the co-cultures in maintaining hepatocyte functions and importantly, introducing heterotypic cell-cell interactions to mimic inflammatory hepatic microenvironment are discussed. Challenges regarding cell source and incorporation of different cells with physical cell-cell contact are outlined and potential solutions are proposed. It is likely that better understanding of the interplay of immune cells in liver models will allow for the development of more accurate systems to better predict hepatotoxicity and stratification of drugs that can cause immune-mediated effects.

Keywords: immune-mediated liver injury, co-culture, human iPSC, macrophages, Kupffer cells, hepatocytes, inflammation

\section{INTRODUCTION}

Drug-induced liver injury (DILI) is a major cause of patient morbidity and mortality and remains a serious problem for clinicians, pharmaceutical industries and regulatory bodies (Hoofnagle and Björnsson, 2019). Although the complex mechanisms of DILI are not fully understood, both nonimmune-mediated and immune-activated mechanisms have been proposed (Waddington et al., 2018). In contrast to non-immune-mediated DILI, prediction of immune-mediated DILI (im-DILI) has been more challenging due to intricate disease pathogenesis, limited knowledge of underlying 
mechanisms and lack of reliable models (Lee and Senior, 2005). The complexity of the system arises in part due to the liver being a unique immunological organ which harbors a rich, diverse array of complementary and interacting innate and adaptive immune cells (Adams et al., 2010; Waddington et al., 2018).

The resident innate immune cells in the liver include macrophages, called Kupffer cells (KCs), dendritic cells (DCs), neutrophils, natural killer (NK) cells and natural killer T (NKT) cells (Liaskou et al., 2012), while $\mathrm{CD}^{+}$and $\mathrm{CD} 8^{+} \mathrm{T}$ cells comprise the adaptative immune system (Waddington et al., 2018). In addition to these cells, the unique vascularization of the liver also allows for the recruitment of circulating leukocytes upon activation of relevant signaling pathways (Liaskou et al., 2012; Mak and Uetrecht, 2017). These immune cells are critical for establishing the balance between host defense against pathogens and tolerance to self- and harmless antigens. In the absence of external stimulus, this balance ensures optimal liver homeostasis. However, in the presence of an infection and/or inflammation, or upon exposure to certain compounds, the balance can be dysregulated, leading to immune cell activation (Krenkel et al., 2014; Waddington et al., 2018). Evolving studies suggest that the direct effects of drugs on hepatic cells might itself be an initiating factor to trigger such an immune response, as exemplified by the case of Acetaminophen (APAP)-mediated immune response (Krenkel et al., 2014). Briefly, KCs form the first line of defense and recognize invading pathogens or necrotic cells resulting from drug injury such as APAP overdose via danger-associated-molecular patterns (DAMPs) and pathogen-associated molecular patterns (PAMPs). KCs release cytokines [e.g., interleukin-6 (IL-6), tumor necrosis factor $\alpha$ $(\mathrm{TNF} \alpha)]$ and chemokines (e.g., C-X-C motif ligand (CXCL)$1 / 3 / 8$ ) upon activation, leading to acute inflammation marked by increased acute phase proteins such as C-reactive protein and complement components (Liaskou et al., 2012). In parallel, released cytokines lead to the upregulation of adhesion molecules in hepatic sinusoidal endothelial cells, while chemokines attract neutrophils and monocytes to the liver. Monocytes differentiate into tissue macrophages $(\mathrm{MoM} \phi)$, and together with the originally resident macrophages (KCs) further release cytokines and factors that promote the survival of neutrophils and hence maintain inflammation. In addition, KC-activated (Krenkel et al., 2014) and DC-activated T-cells (Ogese et al., 2017) have been proposed to be important mediators of inflammation, although exact mechanisms have not been fully clarified yet.

Moreover, the contribution of immune cells is not only restricted to amplification of inflammation following the initial onset of immune activation. Roles of $\mathrm{KCs}, \mathrm{MoM} \phi$ and neutrophils have been reported in tissue repair and alleviation of injury (Shan and Ju, 2019). Specifically, KC and neutrophil death have been shown to promote tissue repair by switching $\mathrm{MoM} \phi$ from pro- to anti-inflammatory states (Triantafyllou et al., 2018; Yang et al., 2019). These MoM $\phi$ in turn induce apoptosis of neutrophils, further resolving inflammation (Holt et al., 2008). Overall, immune cells have a critical role to play in both the augmentation and reduction of inflammation, and by extension in the progression and severity of im-DILI. Therefore, the key to predicting and preventing im-DILI is to first understand the complex interactions between immune cells and other parenchymal/non-parenchymal cells in the liver.

In vivo animal models have been used to model im-DILI (Shenton et al., 2004; Ng et al., 2012; Kuna et al., 2018; Uetrecht, 2019); however, treatment of animals with drugs that are known to cause im-DILI in humans do not cause consistent liver injury in animals, even at high doses (Uetrecht, 2019). Even when liver injury is observed, the characteristics are different from that of humans and possibly manifest through different mechanisms (Ng et al., 2012). In addition to the bottleneck of interspecies variation, animal models are expensive and there is increasing pressure toward reducing animal use in research. Owing to these challenges, significant efforts have been put into developing in vitro models to not necessarily replace, but rather to supplement in vivo animal models. Here, we describe important in vivo and in vitro systems that have been used to model im-DILI, with emphasis on the recent advances in multi-cellular in vitro systems comprising of immune cells to better recapitulate the complexity of the in vivo conditions, aiming to improve the current predictivity of in vitro liver models.

\section{ANIMAL MODELS}

In trying to understand DILI, animal models (especially mice and rat models) have long occupied center stage as the gold standard, becoming part of the regulatory requirement for drug development in almost all jurisdictions. The data gathered using these models has been invaluable, affording us a systemic view of the effects of drug absorption and metabolism, as it was through studying these systems that the role of the immune system in DILI came into the spotlight. Apart from the evident connection between hepatocyte death and the inflammatory response brought on by the DAMPs released during the apoptosis or necrosis of these cells (Martin-Murphy et al., 2010), there are also much more nuanced associations between DILI and the immune system that have been uncovered with the aid of depletion or knockout models.

For instance, KCs, the resident macrophages of the liver and the largest immune population as well, have been implicated in the progression of im-DILI in murine models. However, it is still unclear whether they play a protective or aggravating role. Mice that have been treated with Gadolinium Chloride ( $\mathrm{GdCl} 3$ ) to inhibit $\mathrm{KC}$ activity prior to administration of APAP, appeared to be more resistant to injury, with lower levels of ALT observed after $8 \mathrm{~h}$ as compared to control mice (Michael et al., 1999). Paradoxically, using a chlodronate-liposome based depletion approach seemed to have the opposing effect, as complete depletion of the KCs resulted in increased ALT serum levels, indicative of liver injury (Ju et al., 2002). However, these contrasting results might just be highlighting different aspects of macrophage biology, as $\mathrm{GdCl} 3$ does not deplete macrophages, but rather suppresses their activation and reactive oxygen species (ROS) production. The cross-talk between gut microbes and KCs further complicates the relationship between KCs and imDILI. Lipopolysaccharide (LPS) has been identified as a possible contributing factor to liver injury, as it was observed that 
mice that had been treated with $\mathrm{GdCl} 3$ were more resistant to alcohol-induced liver injury, similar to mice that have had their gut microbes depleted by antibiotics (Thurman et al., 1998). This reduction in liver injury was also seen in animals treated with anti-TNF $\alpha$ antibodies, hinting at the possible relationship between KC activation via LPS-induced TNF $\alpha$ and DILI severity. Later studies strengthened this connection, as mice that were given the broad spectrum antibiotic Trovafloxacin (TVX) alone did not develop DILI, while mice that received both LPS and TVX did (Shaw et al., 2007), similarly in a TNF $\alpha$-dependent manner. KCs have also been shown to directly modulate the metabolic activity of hepatocytes (Odegaard et al., 2008), although the extent to which this contribute to DILI is still unknown and warrants further exploration. Equally intriguing is the possibility of macrophages participating directly in the metabolism of drugs, as several species of cytochrome P450 (CYP450) have been found to be expressed by macrophages in both rodents (Koop et al., 1991) and humans (Hodges et al., 2001).

The use of animal models has also revealed some role for NKT cells, and to a lesser extent NK cells, in the development of im-DILI. An initial study reported that NKT and NK cells contributed to liver injury in the case of APAP-induced toxicity in mice, and that depletion of these populations could significantly reduce the damages seen in these animals (Liu et al., 2004). This was later shown to be an artifact caused by the use of DMSO as the solvent for the APAP (Masson et al., 2008), which triggered the recruitment and activation of NKT and NK cells in the liver. In the absence of DMSO, NKT cells appeared to have a protective effect against APAP induced liver injury instead, with both $\mathrm{CD}_{1} \mathrm{~d}^{-/-}$and $\mathrm{J} \alpha 18^{-/-}$mice having elevated ALT serum levels as compared to the WT control (Martin-Murphy et al., 2013). However, this does not seem to be the case for all drugs though, as $\mathrm{CD} 1 \mathrm{~d}^{-/-}$mice were more resistant to the volatile anesthetic, halothane-induced liver damage, with a corresponding reduction in neutrophil infiltration as well (Cheng et al., 2010).

Although animal models have been immensely helpful, these contradictory results highlight the need for alternative models that can allow us to study specific cell-cell interactions with adjustable complexities to complement these in vivo systems.

\section{IN VITRO MODELS}

\section{Soluble Factor-Driven Single Cultures in Combination With Inflammatory Mediators}

Possibly with the aim to minimize complexity of the models, some studies have tried to mimic inflammatory effects by treating liver parenchymal cells (hepatocytes) with im-DILI-associated cytokines or conditioned media from immune cells instead of directly adding immune cells into the culture (Cosgrove et al., 2009, 2010; Melino et al., 2012; Saab, 2013) (Table 1, Figure 1). It has been demonstrated that conditioned media of THP-1 macrophages caused morphological and functional changes in hepatocytes (Melino et al., 2012). HepG2 cell line deployed in a high-throughput system with a combination of LPS/cytokine/drug co-treatment demonstrated inflammationassociated hepatotoxic potential with four im-DILI drugs (Saab,
2013). Primary rat hepatocytes (pRHs), human hepatocytes (pHHs) and HepG2 utilized in a high throughput drug-cytokine co-treatment approach identified drug-cytokine hepatotoxicity synergies for multiple im-DILI-associated hepatotoxicants, largely potentiated by $\mathrm{TNF} \alpha$, interleukin-1 $\alpha$ (IL- $1 \alpha)$, and LPS (Cosgrove et al., 2009). A follow up study using this approach in combination with multiplex phosphoprotein signaling demonstrated the roles of different protein kinasemediated signaling pathways in drug/cytokine synergy and hepatotoxicity (Cosgrove et al., 2010). These studies may be valuable for elucidating mechanisms in human cells due to their compatibility with high throughput, multiplexed measurements; however, the lack of direct immune cell interaction and crosstalk with hepatocytes remain unaddressed.

Conversely, studies have also tested the effects of drugexposed hepatocyte media (Dragomir et al., 2011; Kegel et al., 2015; Ogese et al., 2017) or direct addition of hepatotoxicants on immune cells including DCs/T cells (Ogese et al., 2017) and KCs (Goto et al., 2015) without including hepatocytes in the culture (Table 1). Adding hepatotoxicants and LPS to rat KCs caused an increase in pro-inflammatory cytokine interleukin-1 beta (IL-1 $\beta$ ) and decrease in anti-inflammatory cytokines IL-6 and interleukin-10 (IL-10) (Goto et al., 2015). However, TNF $\alpha$ secretion remained unchanged which is contradictory to in vivo evidence (Shaw et al., 2010; Monga, 2011). An increase in reactive oxygen intermediates and changes in pro-and anti-inflammatory cytokines when KCs were exposed to APAP or Diclofenac (DIC)treated hepatocyte conditioned media have also been reported (Kegel et al., 2015). Of note, this particular study highlighted the wide donor-dependent variability in cytokine responses across different batches of KCs. Exosomes of drug-treated hepatocytes have been shown to be phagocytosed by monocyte-derived DCs and T cells activated using drug-specific hapten (Ogese et al., 2019). Another study by the same group showed that conditioned medium from hepatocytes treated with im-DILIassociated drugs activated DCs through High-mobility group box 1 protein (HMGB1) and other DAMP molecules, which in turn stimulated T cells (Ogese et al., 2017). HMGB1 was also suggested in a different study to serve as a DAMP in acetaminophen-treated hepatocyte-conditioned media which activated macrophages to produce cytotoxic and proinflammatory mediators known to be involved in hepatotoxicity (Dragomir et al., 2011). In addition, the role of DAMPs in inflammasome activation was tested using human hepatocarcinoma liver cell line, FLC-4, treated with amodiaquine and nevirapine (Kato and Uetrecht, 2017). Drugtreated FLC- 4 conditioned media activated THP-1 macrophages, and while amodiaquine could activate THP-1 directly due to possible metabolization by THP-1, nevirapine did not as it needs to be metabolized primarily by hepatocytes prior to inflammasome activation (Kato and Uetrecht, 2017). Similar inflammasome activation through DAMPs with tolcapone and troglitazone (TGZ)-treated hepatocyte conditioned media have also been reported (Mak et al., 2018). Overall, these studies suggest that hepatotoxicants themselves or DAMP molecules released by apoptotic or necrotic hepatocytes after initial drug injury can be a key triggering factor for the activation of immune cells in the liver. However, the presence of hepatocytes in culture 
TABLE 1 | In vitro models comprising of soluble factors from conditioned media of hepatocytes and immune cells.

\begin{tabular}{|c|c|c|c|c|c|c|c|}
\hline References & Cells & 2D/3D & Duration & $\begin{array}{l}\text { Stimuli } \\
(\mu \mathrm{g} / \mathrm{ml})\end{array}$ & $\begin{array}{l}\text { im-DILI } \\
\text { Compounds }\end{array}$ & Findings & Disadvantages \\
\hline $\begin{array}{l}\text { Melino et al. } \\
(2012)\end{array}$ & $\begin{array}{l}\text { HepG2, } \\
\text { Huh7, THP-1 }\end{array}$ & $\mathrm{CM}$ & $24 \mathrm{~h}$ & NA & NA & $\begin{array}{l}\text { THP1 induce inflammatory } \\
\text { responses in HepG2 }\end{array}$ & No drug testing data. \\
\hline Saab (2013) & HepG2 & $\mathrm{CM}$ & $24 \mathrm{~h}$ & $\begin{array}{l}\text { LPS (20), } \\
\text { TNF } \alpha(0.1)\end{array}$ & $\begin{array}{l}\text { Chlorpromazine, } \\
\text { TVX, } \\
\text { Ranitidine, } \\
\text { Sulindac, } \\
\text { DIC, TGZ }\end{array}$ & $\begin{array}{l}\text { Drug+inflammation } \rightarrow \text { MRP2 } \\
\rightarrow \text { cholestasis }\end{array}$ & Lack of immune cells. \\
\hline $\begin{array}{l}\text { Cosgrove } \\
\text { et al. ( } 2009 \text {, } \\
2010)\end{array}$ & $\begin{array}{l}\text { pHHs, } \\
\text { HepG2, pRHs }\end{array}$ & SC/monolayer & 12/24/48h & $\begin{array}{l}\text { LPS (10), } \\
\text { TNF } \alpha(0.1), \\
\text { IFN (0.1), IL1 } \alpha \\
(0.02)\end{array}$ & $\begin{array}{l}\text { TVX, } \\
\text { Ranitidine, } \\
\text { nefazodone, } \\
\text { nimesulide, } \\
\text { telithromycin } \\
+90\end{array}$ & $\begin{array}{l}19 \% \text { of hepatotoxicants } \\
\text { showed cytokine synergy } \\
\text { effects within } 100^{\star} \mathrm{Cmax} \text {; } \\
\text { follow-up study unveiled the } \\
\text { mechanisms Cosgrove } \\
\text { et al., } 2010 \text {. }\end{array}$ & $\begin{array}{l}\text { No drug-induced } \\
\text { inflammatory response }\end{array}$ \\
\hline $\begin{array}{l}\text { Ogese et al. } \\
(2017)\end{array}$ & $\begin{array}{l}\text { pHHs, } \\
\text { drug-specific } \\
\text { T cell, DCs }\end{array}$ & $\mathrm{CM}$ & $24 \mathrm{~h}$ & SMX-NO & $\begin{array}{l}\text { Flucloxacillin, } \\
\text { INH, } \\
\text { amoxicillin }\end{array}$ & $\begin{array}{l}\text { Flucloxacillin and SMX-NO } \\
\text { prime T cell activity } \\
\text { (HMGB1). }\end{array}$ & / \\
\hline $\begin{array}{l}\text { Dragomir } \\
\text { et al. (2011) }\end{array}$ & $\begin{array}{l}\text { pMHs, } \\
\text { RAW264.7 }\end{array}$ & $\mathrm{CM}$ & $24 \mathrm{~h}$ & NA & APAP & $\begin{array}{l}\text { Upregulation of } \\
\text { pro-inflammatory genes in } \\
\text { RAW264.7 via HGMB1 } \\
\text { travel }\end{array}$ & / \\
\hline $\begin{array}{l}\text { Kegel et al. } \\
(2015)\end{array}$ & $\mathrm{pHHs}, \mathrm{pHKCs}$ & $\mathrm{CM}$ & $2 \mathrm{~h}$ & NA & APAP, DIC & $\begin{array}{l}\text { Drug } \rightarrow \text { cytokine } \\
\text { Donor-matched }\end{array}$ & $\begin{array}{l}\text { Donor-variable cytokine } \\
\text { response }\end{array}$ \\
\hline $\begin{array}{l}\text { Goto et al. } \\
(2015)\end{array}$ & pRKCs & $\mathrm{CM}$ & $24 \mathrm{~h}$ & LPS (0.03) & $\begin{array}{l}\text { APAP, TVX, } \\
\text { TGZ }\end{array}$ & $\begin{array}{l}\text { Drug } \rightarrow \text { cytokine, IL-6/IL-1 } \beta \\
\text { ratio } \downarrow\end{array}$ & $\begin{array}{l}\text { No TVX-induced TNF } \alpha \\
\text { observed }\end{array}$ \\
\hline $\begin{array}{l}\text { Ogese et al. } \\
(2019)\end{array}$ & $\begin{array}{l}\text { pHHs, } \\
\text { drug-specific } \\
\text { T cell, DCs, }\end{array}$ & $\mathrm{CM}$ & $24 \mathrm{~h}$ & SMX-NO & $\begin{array}{l}\text { Flucloxacillin, } \\
\text { INH, } \\
\text { amoxicillin }\end{array}$ & $\begin{array}{l}\text { Drug-specific hapten } \\
\text { activates T cell via exosome }\end{array}$ & / \\
\hline $\begin{array}{l}\text { Kato and } \\
\text { Uetrecht } \\
(2017)\end{array}$ & FLC-4, THP1 & $\mathrm{CM}$ & $7 \mathrm{~d}$ & NA & $\begin{array}{l}\text { Amodiaquine, } \\
\text { Nevirapine }\end{array}$ & $\begin{array}{l}\text { DAMPs released from } \\
\text { FLC- } 4 \text { activate } \\
\text { inflammasome from THP1 }\end{array}$ & / \\
\hline $\begin{array}{l}\text { Mak et al. } \\
(2018)\end{array}$ & $\begin{array}{l}\text { FLC-4, THP1, } \\
\text { J774A.1 }\end{array}$ & $\mathrm{CM}$ & $7 \mathrm{~d}$ & NA & $\begin{array}{l}\text { TGZ, } \\
\text { tolcapone, } \\
\text { entacapone }\end{array}$ & $\begin{array}{l}\text { DAMPs released from } \\
\text { FLC-4 activate } \\
\text { inflammasome from THP1 }\end{array}$ & / \\
\hline
\end{tabular}

pHHs, primary human hepatocytes; pRHs, primary rat hepatocytes; pMHs, primary mouse hepatocytes; pRKCs, primary rat Kupffer cells; pKCs, primary human Kupffer cells; CM, conditioned media; SC, sandwich culture; DCs, dendritic cells; LPS, lipopolysaccharide; TNF $\alpha$, tumor necrosis factor $\alpha$; IFN, interferon; IL-1 $\alpha$, interleukine-1 $\alpha$; APAP, acetaminophen; TVX, trovafloxacin; DIC, diclofenac; TGZ, troglitazone; INH, isoniazid; SMX-NO, nitroso sulfamethoxazole; HGMB1, high-mobility group box 1 protein.

is still required to elucidate their complex crosstalk with immune cells, necessitating the need for more complex co-culture studies.

\section{Co-cultures of Animal Cells}

The majority of animal in vitro hepatocyte culture systems use pRHs, as they are easier to cryopreserve (Swales et al., 1996b) as well as maintain their metabolic functions better than mouse hepatocytes (pMHs) (Swales et al., 1996a). Recognizing the role of immune cells in the progression of DILI as seen in in vivo animal models, there has been some attempts to develop in vitro coculture systems with both hepatocytes and immune cells. These approaches have mainly been restricted to monolayer cultures, although some inroads have also been made into 3 dimensional cultures containing other cell types such as stellate cells that better represent the in vivo environment (Kostadinova et al., 2013).

Given the abundance of macrophages within the liver, it is natural for the focus of immune-hepatocyte systems to be placed on KCs (Kurose et al., 1996; Milosevic et al., 1999;
Tukov et al., 2006; Kostadinova et al., 2013; Bonzo et al., 2015; Rose et al., 2016) (Table 2). These cultures typically involve sorting the hepatocyte and macrophage populations from freshly isolated livers, before putting them back into the same culture. From these cultures, it is evident that some of the inter-cellular interactions are recapitulated in vitro, as stimulating these cocultures often result in greater responses than that of either cell type alone. For example, rat KCs that have been pre-treated with LPS increased Nitrate/Nitrite content in the co-culture supernatant by 11-fold, as opposed to 7 -fold in the case of KCs alone (Kurose et al., 1996). Interestingly, addition of anti-iNOS oligodeoxynucleotide (ODN) to the KCs led to an initial down regulation of Nitrate/Nitrite production in the co-culture after $2 \mathrm{~h}$, which partially recovered at the experimental end-point of $4 \mathrm{~h}$, while addition of the anti-iNOS ODN to the hepatocytes had the opposite effect: with normal Nitrate/Nitrite levels at the $2 \mathrm{~h}$ mark and attenuated expression at the $4 \mathrm{~h}$ time point. This suggested that KCs may have a priming and amplifying role in 

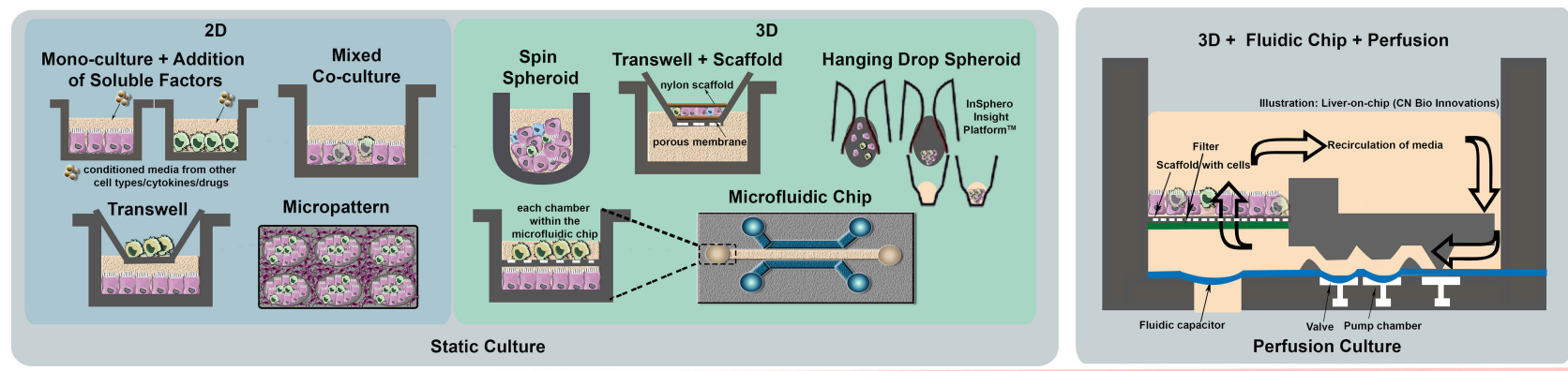

Complex culture systems, higher in vivo relevance but low throughput

Cultures with low complexity, amenabale to high-throughput

OHepatocytes Kupffer Cells Stellate Cells $\nrightarrow$ Fibroblasts

FIGURE 1 | Selection of simple and complex models used for in-vitro liver co-cultures. On the left-hand side, various platforms for static cultures are presented, ranging from simple co-cultures in multi-well plates to more complex systems such as microtissue (hanging drop method), micropatterned surfaces, 3D spheroids formed using scaffolds or microfluidic chips. On the right-hand panel, a macroscopic 3D culture on a chip incorporating a perfusion system is represented using the bioreactor developed by CN Bio Innovations.

TABLE 2 | Animal in vitro liver co-culture models comprising of hepatocytes and immune cells.

\begin{tabular}{|c|c|c|c|c|c|c|c|}
\hline References & Cells & 2D/3D & Duration & $\begin{array}{l}\text { Stimuli } \\
(\mu \mathrm{g} / \mathrm{ml})\end{array}$ & $\begin{array}{l}\text { im-DILI } \\
\text { compounds }\end{array}$ & Findings & Disadvantages \\
\hline $\begin{array}{l}\text { Kurose et al. } \\
\text { (1996) }\end{array}$ & $\begin{array}{l}\text { pRHs, } \\
\text { LPS-pRKCs }\end{array}$ & $2 \mathrm{D}$ & $2 / 4 \mathrm{~h}$ & LPS (1) & / & $\begin{array}{l}\text { LPS-pRKCs } \rightarrow \text { TNF } \alpha \text { and } \\
\text { nitric oxide } \rightarrow \text { Mt dysfunction } \\
\text { in } \mathrm{pRHs}\end{array}$ & No drug testing data \\
\hline $\begin{array}{l}\text { Milosevic } \\
\text { et al. (1999) }\end{array}$ & $\begin{array}{l}\mathrm{pRHs}, \mathrm{pRKCs} \\
\text { (1) }\end{array}$ & Transwell & $48 \mathrm{~h}$ & $\operatorname{LPS}(\leq 10)$ & / & $\begin{array}{l}\text { LPS-induced cytokine in } \\
\text { pRKCs reduced pRHs } \\
\text { functions }\end{array}$ & No drug testing data \\
\hline $\begin{array}{l}\text { Rose et al. } \\
\text { (2016) }\end{array}$ & $\begin{array}{l}\mathrm{pRHs}, \mathrm{pRKCs} \\
(2.5)\end{array}$ & $2 \mathrm{D}$ & $48 \mathrm{~h}$ & LPS (1) & APAP, TVX & $\begin{array}{l}\uparrow \text { Cytotoxicity in co-cultures. } \\
\text { Drugs altered levels of } \\
\text { LPS-induced cytokines }\end{array}$ & $\begin{array}{l}\text { No TVX-induced TNF } \alpha \\
\text { observed }\end{array}$ \\
\hline $\begin{array}{l}\text { Kostadinova } \\
\text { et al. (2013) }\end{array}$ & $\begin{array}{l}\mathrm{pRHs}, \mathrm{NPC} \\
(\sim 1.5)\end{array}$ & $\begin{array}{l}\text { Transwell } \\
\text { scaffold }\end{array}$ & $15 d$ & LPS (10) & $\begin{array}{l}\text { TGZ, TVX, } \\
\text { APAP }\end{array}$ & $\begin{array}{l}\uparrow \text { sensitivity in co-cultures; } \\
\text { species-specific effect } \\
\text { observed. }\end{array}$ & $\begin{array}{l}\text { Drug-induced } \\
\text { inflammatory response } \\
\text { not tested. }\end{array}$ \\
\hline $\begin{array}{l}\text { Tukov et al. } \\
\text { (2006) }\end{array}$ & $\begin{array}{l}\text { pRHs, pRKCs } \\
(0.25)\end{array}$ & $2 \mathrm{D}$ & $6 \mathrm{~h}$ & $\begin{array}{l}\text { LPS }(0.0003 \\
\text { and } 0.01)\end{array}$ & $\begin{array}{l}\text { APAP, } \\
\text { chlorpromazine, } \\
\text { monocrotaline }\end{array}$ & $\begin{array}{l}\text { chlorpromazine, APAP } \\
\rightarrow \uparrow T N F \alpha \\
\text { monocrotaline } \rightarrow \downarrow \text { TNF } \alpha\end{array}$ & \\
\hline $\begin{array}{l}\text { Bonzo et al. } \\
\text { (2015) }\end{array}$ & $\begin{array}{l}\text { pRHs, pRKCs } \\
\text { (2) }\end{array}$ & $2 \mathrm{D}$ & $24 / 48 h$ & LPS (1) & TVX & $\begin{array}{l}\text { TVX } \rightarrow \text { TNF } \alpha \uparrow \\
\text { Ratio of TNF } \alpha / \text { IL- } 6 \downarrow \\
\text { IL-6 downregulated CYP in } \\
\text { pRHs }\end{array}$ & Only one drug tested \\
\hline $\begin{array}{l}\text { Goto et al. } \\
(2015)\end{array}$ & pRKCs & $2 \mathrm{D}$ & $24 \mathrm{~h}$ & LPS (0.03) & $\begin{array}{l}\text { APAP, TVX, } \\
\text { TGZ }\end{array}$ & $\begin{array}{l}\text { Drug } \rightarrow \text { cytokine, } I L-6 / I L-1 \beta \\
\text { ratio } \downarrow\end{array}$ & $\begin{array}{l}\text { No TVX-induced TNF } \alpha \\
\text { observed }\end{array}$ \\
\hline $\begin{array}{l}\text { Poulsen et al. } \\
\text { (2014) }\end{array}$ & RAW264.7 & $2 \mathrm{D}$ & $\begin{array}{l}12 \mathrm{~h} \\
(\mathrm{TVX}-2 \\
\text { LPS-10) }\end{array}$ & LPS (0.01) & TVX $<100$ uM & $\begin{array}{l}\text { TVX-induced TNF } \alpha \text { (ERK, } \\
\text { JNK) }\end{array}$ & Only one drug tested. \\
\hline
\end{tabular}

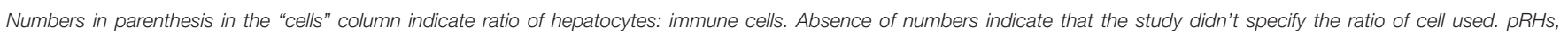

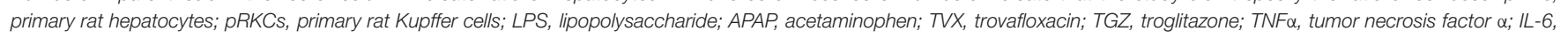

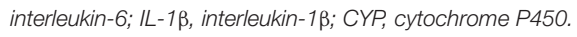

hepatocyte response to stress, in line with our understanding of them as integrative machines (Bleriot and Ginhoux, 2019).

The use of these hepatocyte/KC co-culture systems also helped to validate the role of KCs in the LPS/TNF $\alpha$ induced TVX hepatotoxicity observed in the in vivo animal models. TVX toxicity in hepatocytes was much higher in the co-cultures and was exacerbated by the addition of LPS, while the addition of LPS and TVX to hepatocytes alone was much milder (Bonzo et al., 2015; Rose et al., 2016). However, pro-inflammatory cytokine, $\mathrm{TNF} \alpha$ production did not increase in a dose-dependent manner upon LPS and TVX treatment as observed in vivo (Shaw et al., 2010). These observations are strongly indicative that 
although animal in vitro models are able to partially capture the cellular interactions involved in im-DILI, they are limited in recapitulating in vivo findings.

\section{Co-cultures of Human Cells pHHs and pKCs Co-cultures}

The vast majority of human in vitro co-cultures have focused on co-cultures involving $\mathrm{KCs}$, which is not surprising since they are hepatic resident macrophages comprising of $80-90 \%$ of total macrophages in the human body (Ma et al., 2017). Primary Kupffer cells (pKCs) and pHHs [the gold standard cell source for hepatocytes (Zeilinger et al., 2016)] have been co-cultured in a variety of culture formats including 2D (Sunman et al., 2004), micropatterned (Zinchenko et al., 2006; McVay et al., 2013; Nguyen et al., 2015), microtissue (Nguyen et al., 2016; Jiang et al., 2019; Kermanizadeh et al., 2019a) and microfluidic cultures (Long et al., 2016; Chen et al., 2017; Sarkar et al., 2017) in order to include inflammatory components to in vitro liver models (Table 3, Figure 1). In some of these studies, the authors used a ratio of 10:1 pHHs:pKCs (Long et al., 2016; Chen et al., 2017; Sarkar et al., 2017) in order to match KCs content of about $10 \%$ in the liver (Jones and Summerfield, 1989). However, due to enrichment of KCs in the periportal region under inflammatory conditions in vivo, a ratio of 2.5:1 pHHs:pKCs (Jaeschke, 2007) might be a better representation of inflammatory conditions in vitro (Sunman et al., 2004; Nguyen et al., 2015). In majority of these studies, the co-cultures were stimulated with LPS or cytokines or a combination of both (Sunman et al., 2004; Nguyen et al., 2015; Long et al., 2016; Chen et al., 2017; Sarkar et al., 2017) with the aim of analyzing the inflammatory response mediated by $\mathrm{pKCs}$ and their effects on specific pHHs metabolism. However, the findings of the studies were focused on specific cytokine-hepatocyte interactions such as IL-2 or IL-6 mediated downregulation of CYP3A4 in pHHs (Sunman et al., 2004; Long et al., 2016), an improvement of hepatocyte function and drug metabolism as a result of the co-culture (Zinchenko et al., 2006; Sarkar et al., 2017) and better mimicry of in vivo interactions with other organs such as the gut (Chen et al., 2017). To the best of our knowledge, there are only two reports on the immunemediated effects of a drug. One of them is a $3 \mathrm{D} \mathrm{InSight}{ }^{\mathrm{TM}}$ Human Liver Microtissue (InSphero) which was exposed to APAP (Jiang et al., 2019). APAP-induced production of interleukin8 (IL-8) and IL-6 followed by a suppression of IL-6 in a dose dependent manner was reported. Transcriptomic analyses showed concurrent mitochondrial damage and oxidative stress responses. The results of this study must be interpreted carefully due to the high concentration of LPS used $(10 \mu \mathrm{g} / \mathrm{ml})$ (Jiang et al., 2019), which can cause significant toxicity even without the presence of the drug. The second one is a micropatterned triculture of pHHs, pKCs and fibroblasts (HepatoMune ${ }^{\mathrm{TM}}$, Hepregen/BioIVT) which demonstrated TVX-dependent TNF $\alpha$ increase at low concentrations followed by a decrease at higher concentrations (McVay et al., 2013), although consequent effects on pHHs were not tested. Unfortunately, only one drug was tested in both these models. The remaining culture systems mentioned above were not treated with drugs or compounds or even if they were treated with a single drug, immune-mediated effect of the drug was not tested. Hence the utility of these models in detecting immune-mediated DILI remains to be addressed.

\section{pHHs and Liver Non-parenchymal Cells (NPCs) Co-cultures}

Studies using other sources of immune cells other than pKCs include pHHs co-cultures with NPCs (Novik et al., 2010; Kostadinova et al., 2013; Messner et al., 2013; Esch et al., 2015; Bell et al., 2016). NPCs offer the advantage of testing effects of other hepatic cells such as stellate cells and endothelial cells in addition to KCs. Disadvantages include limited availability, cost, donor variability (Kermanizadeh et al., 2019a) and difficulty in controlling the ratio of pHHs: each NPC cell type; for example, increasing KCs amount to mimic in vivo like inflammatory state would also increase the number of stellate cells, endothelial cells or fibroblasts in culture. Interestingly, a ratio of 1.5:1 pHHs: NPCs, was used for some of the studies (Kostadinova et al., 2013; Esch et al., 2015) with the intention to mimic 60\% parenchymal and $40 \%$ non-parenchymal cells in vivo; however, this ratio doesn't mimic in vivo inflammatory state in terms of KCs where pHHs:KCs ratio is about 2.5:1 (Jaeschke, 2007), nor is it clear whether in vivo content of other NPCs such as stellate cells (5-8\%) is being mimicked (Yin et al., 2013). Of note is also the concentration of LPS used in these studies: $10-50 \mu \mathrm{g} / \mathrm{ml}$ which is significantly higher than concentrations used in most co-culture studies $(50 \mathrm{ng} / \mathrm{ml}$ to $1 \mu \mathrm{g} / \mathrm{ml}$ ) (Nguyen et al., 2015; Granitzny et al., 2017; Sarkar et al., 2017; Tasnim et al., 2019) and physiologically relevant concentrations (Desch et al., 1989). Irrespective of the culture conditions, the studies showed that pHHs functions could be stabilized for longterm cultures ( $\geq 14$ days) in the presence of NPCs, which was similar to findings in pHHs-pKCs co-cultures. Unlike pHHspKCs co-cultures, several drugs were tested in the pHHs-NPCs co-cultures: APAP (Kostadinova et al., 2013; Messner et al., 2013), TVX (Kostadinova et al., 2013; Messner et al., 2013), DIC (Messner et al., 2013; Bell et al., 2016) and TGZ (Kostadinova et al., 2013). In addition, Bell et al. treated their co-culture with Amiodarone, Bosentan, Fialuridine and Tolcapone (Bell et al., 2016). However, only the cytotoxic effects of the drugs were tested, showing improved sensitivity, i.e., detection of toxicity at lower concentrations in pHHs-NPCs co-cultures when compared to pHHs mono-cultures (Kostadinova et al., 2013; Messner et al., 2013; Bell et al., 2016). Immune-mediated effects of the drugs in the system were not tested.

\section{Hepatic Cell Lines and THP-1 Co-cultures}

Probably due to the cost and lack of availability of pKCs and NPCs, some studies have used alternative cell sources such as human hepatoblastoma cell line HepG2 and THP1 monocytes/macrophages for the development of co-cultures (Granitzny et al., 2017; Wewering et al., 2017). The former reported increased cytotoxicity in THP-macrophage co-cultures, but not in THP-monocyte co-cultures in response to TGZ, TVX, DIC and Ketoconazole (KCL) in the presence of inflammatory stimulus: LPS and TNF $\alpha$. The latter demonstrated co-culture specific induction of NRF2-mediated stress response and proinflammatory cytokines (CXCL8, TNF $\alpha$ and C-C motif ligand 
TABLE 3 | Human in vitro liver co-culture models comprising of hepatocytes and immune cells.

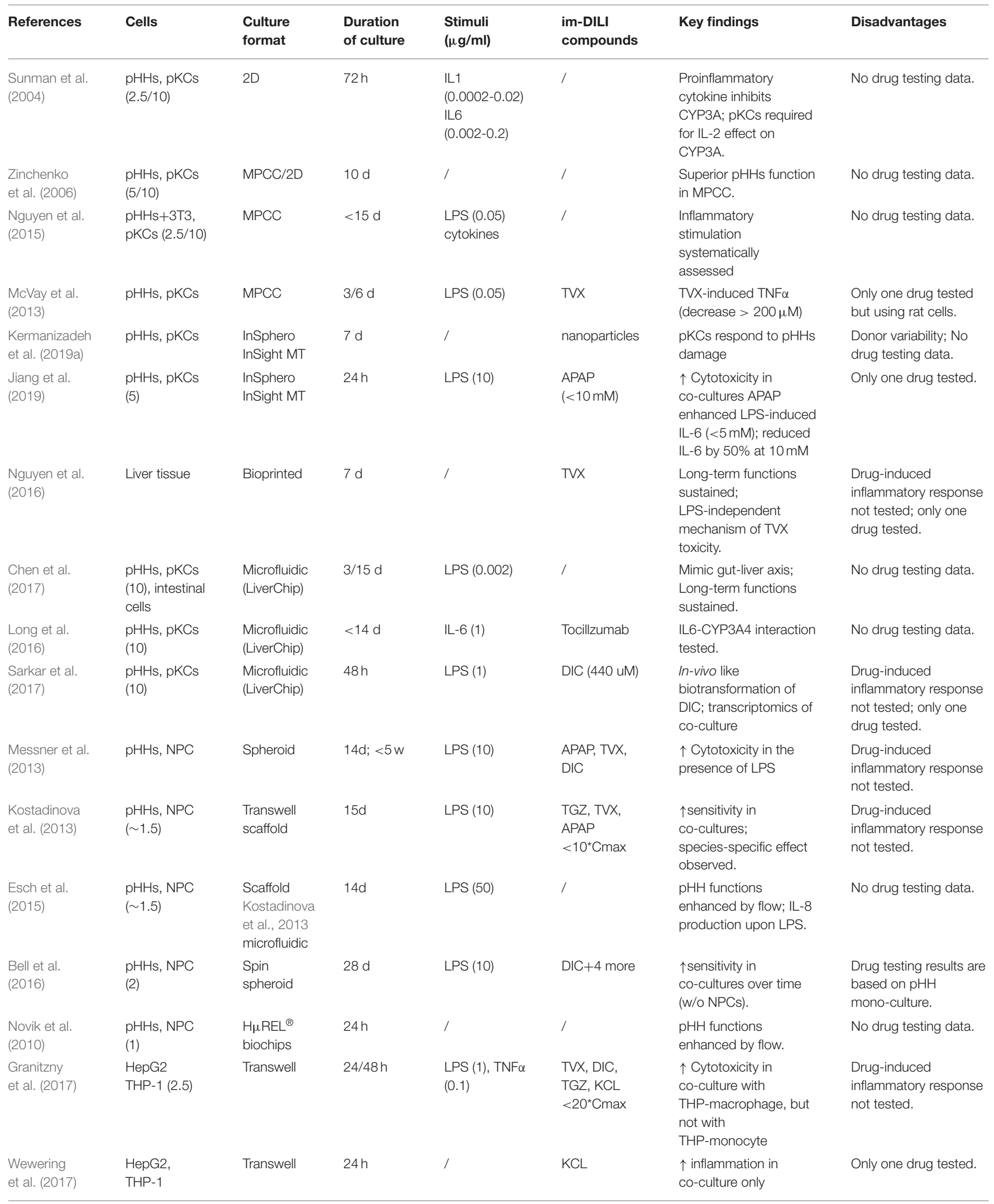


TABLE 3 | Continued

\begin{tabular}{|c|c|c|c|c|c|c|c|}
\hline References & Cells & $\begin{array}{l}\text { Culture } \\
\text { format }\end{array}$ & $\begin{array}{l}\text { Duration } \\
\text { of culture }\end{array}$ & $\begin{array}{l}\text { Stimuli } \\
(\mu \mathrm{g} / \mathrm{ml})\end{array}$ & $\begin{array}{l}\text { im-DILI } \\
\text { compounds }\end{array}$ & Key findings & Disadvantages \\
\hline $\begin{array}{l}\text { Edling et al. } \\
\text { (2009) }\end{array}$ & $\begin{array}{l}\text { Huh7, THP-1 } \\
(2.5)\end{array}$ & Transwell & $24 \mathrm{~h}$ & / & TGZ & $\begin{array}{l}\uparrow \text { Cytotoxicity and } \\
\text { stress responses in } \\
\text { co-culture }\end{array}$ & $\begin{array}{l}\text { Drug-induced } \\
\text { inflammatory response } \\
\text { not tested; only one } \\
\text { drug tested. }\end{array}$ \\
\hline $\begin{array}{l}\text { Fasbender } \\
\text { et al. (2020) }\end{array}$ & $\begin{array}{l}\text { Huh7, } \\
\text { HepG2, } \\
\text { pHHs; } \\
\text { PBMCNK }\end{array}$ & $2 \mathrm{D}$ & $\begin{array}{l}\text { Drug-24h, } \\
\text { add NK }\end{array}$ & / & $\begin{array}{l}\mathrm{INH}, \mathrm{KCL} \\
\text { promethazine, } \\
\text { valproic acid }\end{array}$ & $\begin{array}{l}\text { Upregulation of NK cell } \\
\text { ligand on hep exposed } \\
\text { to drugs; } \uparrow \text { Cytotoxicity } \\
\text { in co-culture }\end{array}$ & $\begin{array}{l}\text { HLA-unmatched } \\
\text { co-culture }\end{array}$ \\
\hline
\end{tabular}

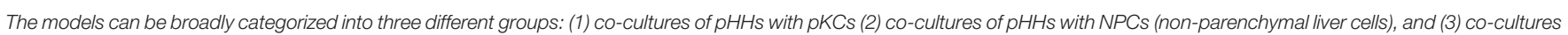

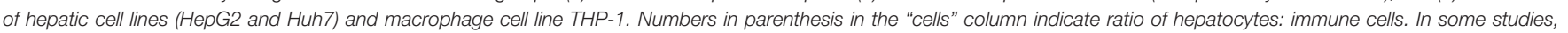

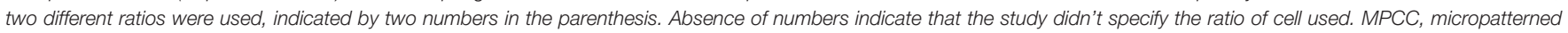

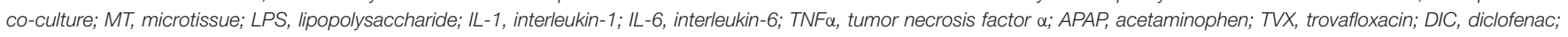
$T G Z$, troglitazone; INH, isoniazid; KCL, ketoconazole; NPCs, non-parenchymal cells.

(CCL)-3) upon treatment with KCL. A co-culture of the human hepatoma cell line Huh7 and THP-1 showed that TGZ exposure led to an increase in gene expression of pro-inflammatory cytokines and stress-related genes in both cell types (Edling et al., 2009). Although pro-inflammatory cytokines such as IL$1 \beta$ was elevated in the co-culture, $\mathrm{TNF} \alpha$, a key pro-inflammatory cytokine was in fact downregulated. This might be due to the fact that cell lines are often not functionally similar to primary cells as exemplified by the differences in cytokine profiles of THP-1, KCs and human blood-derived primary macrophages following compound exposure (Kermanizadeh et al., 2019b).

\section{Hepatic Cell Lines and NK Co-cultures}

Most studies involving hepatic interactions with immune cells other than macrophages (e.g., NK cells, DCs and T cells) have been conducted with drug exposed-hepatocyte conditioned media (section Soluble Factor-Driven Single Cultures in Combination With Inflammatory Mediators). There are limited reports of direct co-cultures of hepatocytes and these immune cells. The only report of a direct co-culture is a study of human hepatocyte cell lines Huh7/HepG2 and peripheral blood mononuclear cell (PBMC)-derived NK cells which demonstrated enhanced NK cell activation and upregulation of NK cell ligands in Huh7/HepG2 after exposure to isoniazid (INH), KCL, Promethazine and Valproic acid (Fasbender et al., 2020). Increased cytotoxicity and interferon (IFN) $-\gamma$ production were observed. This study demonstrated that, in addition to macrophages, NK cells can modulate im-DILI through direct interactions with hepatocytes.

Despite these studies contributing to significant progress in the field, most published studies were unfortunately limited to a single or handful of drugs and exposure scenarios. Hence, further work needs to be done for the establishment of a general im-DILI testing system that can be applied to structurally and mechanistically diverse im-DILI-associated compounds. One major challenge in performing such comprehensive studies is the lack of a source of relevant, functional cells that can be generated in large numbers. Cell lines (macrophages: mouse RAW264.7, human THP cell lines and hepatocytes: HepG2 and Huh7) can resolve the cell number issue but often do not represent the complex functions of primary cells (Kaur and Dufour, 2012). On the other hand, primary cells are expensive, show donor variability (Stoddart et al., 2012; Kegel et al., 2015; Kermanizadeh et al., 2019a), not easily accessible and cannot be expanded extensively in in vitro culture (Honegger, 1999).

\section{Induced Pluripotent Stem Cells Co-cultures}

Generation of induced pluripotent stem cells (iPSCs)-derived cell types provide an attractive alternative due to their accessibility, renewability and scalability (Shi et al., 2017; Doss and Sachinidis, 2019). Although generation of iPSC-derived hepatocytes (iHeps) have been established over the past decade both by us (Tasnim et al., 2015, 2016; Mittal et al., 2016) and others (Hannoun et al., 2016; Maepa and Ndlovu, 2020), iPSC-derived macrophages (iMacs), especially iPSC-derived KCs (iKCs) and other immune cells generated from iPSCs (Trump et al., 2019) are still in their infancy (Lee et al., 2018). We have recently published the first report to generate iKCs from iPSC-derived macrophage precursors (preM $\phi)$ by providing the preM $\phi$ with hepatic cues (Tasnim et al., 2019). The transcriptomic profile of iKCs was distinct from bone marrow-derived macrophages, alveolar macrophages, non-liver macrophages as demonstrated by principal component analysis. iKCs were similar to pKCs in terms of marker expression and functions and could mimic pKCs in detecting hepatotoxicity of im-DILI associated drugs APAP and TVX when co-cultured with pHHs or iHeps (Tasnim et al., 2019). This is not trivial since iPSC-derived cells are often reported to be immature and have lower functions compared to their primary counterparts (Doss and Sachinidis, 2019; Volpato and Webber, 2020). We are currently working on two different aspects to improve and further validate our co-culture model.

The first aspect is a direct co-culture of iHeps and iMacs for providing iMacs with a hepatic niche in order to differentiate toward a hepatic linage i.e., iKCs (in our previous study iKCs were generated using hepatic conditioned media and not a direct co-culture with hepatocytes (Tasnim et al., 2019). Other than providing direct cellular interactions, this system has the advantage of allowing generation of iKCs and iHeps from the 
same donor. Hepatocytes cultured with KCs (Tasnim et al., 2019) and T cells (Figueiredo et al., 2019) from different donors have shown activation of the respective immune cells. Alloreactivity could be reduced by silencing of HLA I on pHHs (Figueiredo et al., 2019). Donor-matched iKCs and iHeps developed by us would not require such additional measures to suppress immune reactions.

The second aspect we focus on is the application of the co-culture model to a diverse array and larger number of imDILI associated drugs to validate if our model can stratify drugs based on their immune-mediated effects. Detailed cytokine production by iKCs upon treatment with each drug and their consequent effect on iHeps are being assayed. We are also analyzing correlation of the in vitro findings to clinical data to assess the physiological relevance of our model. Finally, such model might provide hints toward more sensitive hepatotoxicity endpoints as opposed to conventional cell viability assays.

\section{TECHNICAL CHALLENGES IN ESTABLISHING CO-CULTURE}

Despite the benefits of incorporating immune cells to investigate im-DILI, some key technical questions need to be addressed for co-culturing hepatocytes and immune cells: (1) How do we obtain a steady source of the appropriate immune cells, especially for human cultures? (2) For how long do functional co-cultures need to be maintained? (3) How do we balance the use of components essential for one cell type but harmful for the counterpart, such as serum and growth factor? (4) Are immune cells primed when being in contact to HLA-unmatched hepatocytes? (5) How well do in vitro cells recapitulate human pathophysiology?

Although similar difficulties also exist when trying to model hepatocyte only cultures, obtaining the appropriate human resident immune cells, KCs in this case, poses a unique challenge. Even though KCs are the largest immune population in the liver, they still only make up $10 \%$ of the liver, which makes obtaining and using primary KCs in co-culture screening models prohibitively expensive. Blood monocytes have been explored as a possible surrogate for KCs in co-culture models (Rennert et al., 2016), however with our current understanding of macrophage ontogeny (Ginhoux and Jung, 2014; Perdiguero et al., 2015), they might be an inadequate substitute. We now know that, as seen in the various murine fate mapping models (Hoeffel et al., 2015), human KCs are also initially seeded by non-hematopoietic stem cell derived embryonic macrophages (Bian et al., 2020). This has far-reaching consequences, as embryonic macrophages have been shown to maintain a distinct transcriptomic and epigenetic landscape in the murine models and are self-renewing well into adulthood under steady state conditions (Lavin et al., 2014). Thankfully, this is not an insurmountable challenge, as murine iMacs have been shown to be similar to embryonic yolk sac macrophages (Takata et al., 2017), and so human iMacs, especially in a hepatic environment, may prove to be a suitable KC surrogate in im-DILI co-culture models.
Developing a suitable $\mathrm{KC}$ surrogate is also dependent on overcoming a separate but related problem: defining human $\mathrm{KC}$ identity and their development and specification trajectories. Although the differentiation of murine KCs is well-studied (van de Laar et al., 2016), some of the markers used to distinguish KCs from macrophages are not applicable to humans. An example of this would be CLEC4F, which is considered a definitive $\mathrm{KC}$ marker in mice, but does not encode for a functional receptor in humans (Taylor et al., 2019). Furthermore, using a handful of surface markers to claim identity of cells raised in vitro can be misleading, as cells can downregulate or even lose expression of markers after prolong culture. This limitation is starting to be addressed by the increased adoption of high dimensional techniques such as bulk and single cell RNAseq (scRNAseq) and ATACseq, allowing for a more holistic view of macrophage development and tissue interactions. For instance, scRNAseq has allowed us to observe the step-wise transcriptomic changes that occur along KC specification in the human embryo (Bian et al., 2020), providing a reference framework for in vitro $\mathrm{KC}$ development. The large volume of data generated by these techniques also enables the use of powerful new tools such as CellPhoneDB to interrogate macrophage-tissue interactions (Efremova et al., 2020), which can help us to better understand injury mechanisms and identity therapeutic targets in future im-DILI models.

Long-term cultures are important for recapitulating the latency of im-DILI (Chalasani et al., 2015), which can be intermediate (1-8 weeks) or long (up to 12 months) (Liu and Kaplowitz, 2002). It is challenging to maintain the morphology and functions of hepatocytes on common 2D culture over extended periods (Richert et al., 2006). Long-term hepatocyte cultures have been maintained using more complex designs including 3D cultures (Mittal et al., 2016; Tasnim et al., 2016; Lauschke et al., 2019) and co-cultures [mainly with fibroblasts (March et al., 2015)]. Some of the long-term culture models which involve co-culture with immune cells have been described in section Co-cultures of Human Cells and Table 3. Hepatocyte functions were well-maintained for at least 1-2 weeks in both serum-containing (Zinchenko et al., 2006; Kostadinova et al., 2013) and serum-free conditions (Messner et al., 2013; Nguyen et al., 2015, 2016; Bell et al., 2016; Long et al., 2016) with the aid of supportive mechanical environment such as microtissue, microfluidics and spheroids. However, complex culture systems are not conducive to high throughput applications. When a less complex high-throughput model is required for long-term culture, optimization of medium conditions becomes necessary.

Medium is a critical factor for optimal cell function in vitro. This comprises of the basal medium and supplements including serum. Various immune cells share similar culture conditions: RPMI 1640 (basal medium) with 10\% serum, sometimes supplemented with growth factors, is commonly used (Moore et al., 1967; Exley et al., 2010). Use of RPMI 1640 for hepatocyte culture has also been reported (Burdon and van Knippenberg, 1991) and was comparable to William's E Medium (WEM) up to 6 days of culture (Nelson et al., 2013). Hence, RPMI 1640 (without serum) could be used for short-term co-culture of hepatocytes and immune cells. In agreement with this, Sana 
et al. for instance, used RPMI 1640 for co-culture of hepatocytes and PBMCs and DCs for up to $96 \mathrm{~h}$ (Sana et al., 2014). The effect of RPMI 1640 or other suitable basal media (e.g., WEM) on long-term co-cultures of hepatocytes and immune cells needs to be addressed.

Compared to basal medium, the use of serum is more contradictory. On one hand, despite the heterogeneity of serum composition from different lots and origins, it is essential for in vitro expansion and for obtaining optimal cell functions of immune cells (Musson, 1983; Costello et al., 2000). On the other hand, serum is deleterious to human hepatocyte culture due to inhibition of important cell functions (Enat et al., 1984). In most cases, hepatocytes favor serum-free medium supplemented with insulin-transferrin-selenium (ITS) and dexamethasone (Chard et al., 1987). We postulate that serum-free medium should be developed for co-cultures of hepatocytes and immune cells. A serum-free condition has been established for human KC culture by Tasnim et al. (2019). KCs were cultured with advanced DMEM plus Cocktail $\mathrm{B}^{\mathrm{TM}}$ (containing ITS) and in WEM plus Cocktail $\mathrm{B}^{\mathrm{TM}}$ when co-cultured with hepatocytes without functional compromise (Tasnim et al., 2019). Serum-free medium for immune cell cultures has been being development for decades, including AIM V ${ }^{\mathrm{TM}}$ and X-VIVO15 ${ }^{\mathrm{TM}}$ (Medvec et al., 2018), but has yet to be tested for hepatocytes' functions, especially for long term co-cultures.

Another important challenge which might often go unnoticed is the frequency of media change. On one hand, a high frequency of media change is not conducive to the interaction of hepatocytes and immune cells through soluble factors. On the other hand, hepatocytes are highly metabolic cells and hence require frequent media change (typically, hepatocyte media is changed daily). Therefore, co-culture conditions need to be tuned carefully in order to strike a delicate balance. To this effect, we have optimized a method to co-culture iMacs and iHeps for up to 1 week with ideal media change frequency and re-defined media supplement concentrations (unpublished data). It will be interesting to assess if these conditions work for longer time periods and other immune cell co-cultures.

Notably, glucocorticoids (GCs), such as dexamethasone, is essential to maintain hepatocytes' functions particularly in extended period (Bailly-Maitre et al., 2001); however, they pose potent anti-inflammatory effects on immune cells, including macrophages (Werb, 1978; Rose et al., 2016), NK cells (Bush et al., 2012) and $\mathrm{T}$ cells (Ashwell et al., 2000). We also observed significant inhibitory effects of dexamethasone on $\mathrm{pKCs}$ and iKCs (data not shown). Conversely, low concentration of corticosterone $(0.1 \mathrm{nM})$ was reported to enhance proinflammatory responses in rat PBMC (Lim et al., 2007). Despite such discrepancy, there are two options to resolve this: (1) Co-culture without dexamethasone which did not show any functional compromise in iHeps for short-term cultures (Tasnim et al., 2019) or (2) Selection of an appropriate GC to both maintain hepatocyte functions and retain cytokine production from KCs as demonstrated by Rose et al. (2016). Their results suggested that a less potent GC hydrocortisone might be used during the plating phase for the co-culture. However, whether these two options are applicable for long-term cultures needs to be systematically examined.
In addition, the need for HLA-matched cells in co-cultures should also be addressed. Due to limited accessibility to hepatocytes/immune cells, it is challenging to frequently obtain cells from the same donor. Many of the co-culture studies have to proceed with cells from different donors, indicating extremely low possibility of obtaining HLA-matched co-cultures. This might pose a challenge as HLA-unmatched co-cultures have shown to activate KCs (Long et al., 2016; Tasnim et al., 2019) and T cells (Figueiredo et al., 2019). Even though co-culture with transwell setup could attenuate the pre-activity of immune cells by reducing physical contact, it was also reported that HLA could travel through exosome to stimulate other immune cells (De Toro et al., 2015) or the paracrine factors secreted from immune cells could be sufficient for alloreactivity (Figueiredo et al., 2019; Tasnim et al., 2019). Strategies to reduce such activity include the use of the immune cells harboring the most frequent HLA class, or leveraging on donor-matched cells derived from human iPSCs.

Finally, careful consideration must be given to the interpretation of any functional readouts obtained from the stimulation of in vitro cells. These co-culture model systems are useful for the understanding of cell-to-cell interactions under specific defined conditions, and we should be careful not to overinterpret them in relation to complex human pathophysiology. As seen in a few of the studies mentioned previously, non-physiological concentrations of stimulants are sometimes used, partially in recognition of the decreased metabolic sensitivity of cells in culture, but often simply to obtain a response from these cells. One way around this issue might be the integration of in silico approaches with in vitro experiments. Using meta-analyses, possible pathways of im-DILI can be identified (Selvaraj et al., 2020), then experimentally tested using the relevant human in vitro systems. The results from these experiments can then be compared to clinical diagnoses and observations from human patients, giving a more holistic view of the adverse event.

\section{CONCLUSION AND FUTURE PERSPECTIVES}

Immune-mediated toxicity can involve many different cell types in various locations and can develop over a wide timeframe. A conceivable mechanism of im-DILI that has been proposed starts from reactive metabolite formation in the liver, followed by drug-modified proteins and release of DAMPs (Uetrecht, 2019). This in turn involves migration of antigen presenting cells to lymph nodes and spleen, where $\mathrm{T}$ cells are activated and return to the liver to mediate injury. It would be extremely challenging to duplicate this process in vitro; not only due to the complexity of the culture system involving hepatocytes, KCs, DCs and T cells, but also because the system has to be architecturally designed to mimic the sequence of events. Therefore, caution needs to be exercised when extrapolating the data obtained from in vitro studies to human pathophysiology. Specifically, it would not be appropriate to deduce immune-mediated injury mechanisms from the 
results of these studies unless predictions obtained from the data are consistent with characteristics of immune-mediated toxicity in patients. In light of this, our recent work has focused on identifying drugs that have clear immune-mediated responses in patients (e.g., changes in specific cytokine levels upon drug treatment) and validating if those specific changes are recapitulated in our in vitro model (unpublished data). In this manner, we could recapitulate certain elements of immune-mediated toxicity in vitro. Nevertheless, further efforts need to focus on improving the performance of in vitro models so that they can reproduce more aspects of human pathophysiology. In this regard, we postulate several strategies. Systematic evaluation of conditions for long-term co-cultures and development of microfluidic chip for temporal control of intercellular interaction are encouraged. While classical studies with primary cells and cell lines have helped to advance the field immensely; we now have more options for cell sources through establishment of iPSC-derived immune cells. Hence, renewable and functional cell source of other immune cells could be developed from human iPSC to overcome the low accessibility of liver cells and to facilitate establishment of HLAmatched co-cultures. Through this review, we highlight the gaps in investigating im-DILI in-vitro in order to encourage multidisciplinary efforts to improve the understanding and modeling of im-DILI. Such developments will greatly enhance drug safety assessment, especially in terms of predicting immune reactions elicited by drugs.

\section{REFERENCES}

Adams, D. H., Ju, C., Ramaiah, S. K., Uetrecht, J., and Jaeschke, H. (2010). Mechanisms of immune-mediated liver injury. Toxicol. Sci. 115, 307-321. doi: $10.1093 /$ toxsci/kfq009

Ashwell, J. D., Lu, F. W., and Vacchio, M. S. (2000). Glucocorticoids in $\mathrm{T}$ cell development and function. Annu. Rev. Immunol. 18, 309-345. doi: 10.1146/annurev.immunol.18.1.309

Bailly-Maitre, B., De Sousa, G., Boulukos, K., Gugenheim, J., and Rahmani, R. (2001). Dexamethasone inhibits spontaneous apoptosis in primary cultures of human and rat hepatocytes via Bcl-2 and Bcl-xL induction. Cell Death Differ. 8, 279-288. doi: $10.1038 /$ sj.cdd. 4400815

Bell, C. C., Hendriks, D. F., Moro, S. M., Ellis, E., Walsh, J., Renblom, A., et al. (2016). Characterization of primary human hepatocyte spheroids as a model system for drug-induced liver injury, liver function and disease. Sci. Rep. 6:25187. doi: 10.1038/srep25187

Berry, M. N., Edwards, A. M., and Barritt, G. J. (1991). "Monolayer culture of depatocytes," in Laboratory techniques in Biochemistry and Molecular Biology, Vol. 21, eds R. H. Burdon, and P. H. van Knippenberg (Amsterdam: Elsevier), 265-354.

Bian, Z., Gong, Y., Huang, T., Lee, C. Z. W., Bian, L., Bai, Z., et al. (2020). Deciphering human macrophage development at single-cell resolution. Nature. 582, 571-576. doi: 10.1038/s41586-020-2316-7

Bleriot, C., and Ginhoux, F. (2019). Understanding the heterogeneity of resident liver macrophages. Front. Immunol. 10:2694. doi: 10.3389/fimmu.2019.02694

Bonzo, J. A., Rose, K., Freeman, K., Deibert, E., Amaral, K. B., Ferguson, S. S., et al. (2015). Differential effects of trovafloxacin on TNF- $\alpha$ and IL-6 profiles in a rat hepatocyte-Kupffer cell coculture system. Appl. In Vitro Toxicol. 1, 45-54. doi: 10.1089/aivt.2014.0004

Bush, K. A., Krukowski, K., Eddy, J. L., Janusek, L. W., and Mathews, H. L. (2012). Glucocorticoid receptor mediated suppression of natural killer cell

\section{AUTHOR CONTRIBUTIONS}

All authors listed have made a substantial, direct and intellectual contribution to the work, and approved it for publication.

\section{FUNDING}

The authors were supported by the Agency for Science, Technology and Research (A*STAR) under its Industry Alignment Fund-Pre-Positioning Programme (IAF-PP) (Grant Number H18/01/a0/D14) as part of the A*STAR Innovations in Food and Chemical Safety (IFCS) Programme as well as Institute of Bioengineering and Nanotechnology (IBN) and Singapore Immunology Network (SIgN) core funding. FG was a European Molecular Biology Organization (EMBO) YIP awardee and supported by the Singapore National Research Foundation Senior Investigatorship (NRFI) NRF2016NRF-NRFI001-02. $\mathrm{XZH}$ was a research scholar of the National University of Singapore. CZWL was supported by the A*STAR Graduate Scholarship.

\section{ACKNOWLEDGMENTS}

We also thank Dr. Yao Teng for her advice on fluidic device illustration.

activity: identification of associated deacetylase and corepressor molecules. Cell. Immunol. 275, 80-89. doi: 10.1016/j.cellimm.2012.02.014

Chalasani, N., Bonkovsky, H. L., Fontana, R., Lee, W., Stolz, A., Talwalkar, J., et al. (2015). Features and outcomes of 899 patients with drug-induced liver injury: the DILIN prospective study. Gastroenterology 148, 1340-1352.e1347. doi: 10.1053/j.gastro.2015.03.006

Chard, T., Work, T., and Work, E. (1987). Laboratory Techniques in Biochemistry and Molecular Biology. Amsterdam: Elsevier.

Chen, W. L., Edington, C., Suter, E., Yu, J., Velazquez, J. J., Velazquez, J. G., et al. (2017). Integrated gut/liver microphysiological systems elucidates inflammatory inter-tissue crosstalk. Biotechnol. Bioeng. 114, 2648-2659. doi: 10.1002/bit.26370

Cheng, L., You, Q., Yin, H., Holt, M. P., and Ju, C. (2010). Involvement of natural killer T cells in halothane-induced liver injury in mice. Biochem. Pharmacol. 80, 255-261. doi: 10.1016/j.bcp.2010.03.025

Cosgrove, B. D., Alexopoulos, L. G., Hang, T.-C., Hendriks, B. S., Sorger, P. K., Griffith, L. G., et al. (2010). Cytokine-associated drug toxicity in human hepatocytes is associated with signaling network dysregulation. Mol. Biosyst. 6, 1195-1206. doi: 10.1039/b926287c

Cosgrove, B. D., King, B. M., Hasan, M. A., Alexopoulos, L. G., Farazi, P. A., Hendriks, B. S., et al. (2009). Synergistic drug-cytokine induction of hepatocellular death as an in vitro approach for the study of inflammationassociated idiosyncratic drug hepatotoxicity. Toxicol. Appl. Pharmacol. 237, 317-330. doi: 10.1016/j.taap.2009.04.002

Costello, E., Munoz, M., Buetti, E., Meylan, P., Diggelmann, H., and Thali, M. (2000). Gene transfer into stimulated and unstimulated T lymphocytes by HIV1-derived lentiviral vectors. Gene Ther. 7, 596-604. doi: 10.1038/sj.gt.3301135

De Toro, J., Herschlik, L., Waldner, C., and Mongini, C. (2015). Emerging roles of exosomes in normal and pathological conditions: new insights for diagnosis and therapeutic applications. Front. Immunol. 6:203. doi: 10.3389/fimmu.2015.00203 
Desch, C. E., Kovach, N., Present, W., Broyles, C., and Harlan, J. (1989). Production of human tumor necrosis factor from whole blood ex vivo. Lymphokine Res. 8, 141-146.

Doss, M. X., and Sachinidis, A. (2019). Current challenges of iPSC-based disease modeling and therapeutic implications. Cells 8:403. doi: 10.3390/cells8050403

Dragomir, A.-C., Laskin, J. D., and Laskin, D. L. (2011). Macrophage activation by factors released from acetaminophen-injured hepatocytes: potential role of HMGB1. Toxicol. Appl. Pharmacol. 253, 170-177. doi: 10.1016/j.taap.2011.04.003

Edling, Y., Sivertsson, L. K., Butura, A., Ingelman-Sundberg, M., and Ek, M. (2009). Increased sensitivity for troglitazone-induced cytotoxicity using a human in vitro co-culture model. Toxicol. In Vitro 23, 1387-1395. doi: 10.1016/j.tiv.2009.07.026

Efremova, M., Vento-Tormo, M., Teichmann, S. A., and Vento-Tormo, R. (2020). CellPhoneDB: inferring cell-cell communication from combined expression of multi-subunit ligand-receptor complexes. Nat. Protoc. 15, 1484-1506. doi: 10.1038/s41596-020-0292-x

Enat, R., Jefferson, D. M., Ruiz-Opazo, N., Gatmaitan, Z., Leinwand, L. A., and Reid, L. M. (1984). Hepatocyte proliferation in vitro: its dependence on the use of serum-free hormonally defined medium and substrata of extracellular matrix. Proc. Natl. Aca. Sci. U. S. A. 81, 1411-1415. doi: 10.1073/pnas.81.5.1411

Esch, M. B., Prot, J.-M., Wang, Y. I., Miller, P., Llamas-Vidales, J. R., Naughton, B. A., et al. (2015). Multi-cellular 3D human primary liver cell culture elevates metabolic activity under fluidic flow. Lab Chip 15, 2269-2277. doi: 10.1039/C5LC00237K

Exley, M. A., Wilson, B., and Balk, S. P. (2010). Isolation and functional use of human NKT cells. Curr. Protoc. Immunol. 90, 14.11.11-14.11.17. doi: 10.1002/0471142735.im1411s90

Fasbender, F., Obholzer, M., Metzler, S., Stöber, R., Hengstler, J. G., and Watzl, C. (2020). Enhanced activation of human NK cells by drug-exposed hepatocytes. Arch. Toxicol. 94, 439-448. doi: 10.1007/s00204-020-02668-8

Figueiredo, C., Oldhafer, F., Wittauer, E. M., Carvalho-Oliveira, M., Akhdar, A., Beetz, O., et al. (2019). Silencing of HLA class I on primary human hepatocytes as a novel strategy for reduction in alloreactivity. J. Cell. Mol. Med. 23, 5705-5714. doi: $10.1111 /$ jcmm. 14484

Ginhoux, F., and Jung, S. (2014). Monocytes and macrophages: developmental pathways and tissue homeostasis. Nat. Rev. Immunol. 14, 392-404. doi: $10.1038 /$ nri3671

Goto, S., Deguchi, J., Nishio, N., Nomura, N., and Funabashi, H. (2015). Hepatotoxicants induce cytokine imbalance in response to innate immune system. J. Toxicol. Sci. 40, 389-404. doi: 10.2131/jts.40.389

Granitzny, A., Knebel, J., Müller, M., Braun, A., Steinberg, P., Dasenbrock, C., et al. (2017). Evaluation of a human in vitro hepatocyte-NPC co-culture model for the prediction of idiosyncratic drug-induced liver injury: a pilot study. Toxicol. Rep. 4, 89-103. doi: 10.1016/j.toxrep.2017.02.001

Hannoun, Z., Steichen, C., Dianat, N., Weber, A., and Dubart-Kupperschmitt, A. (2016). The potential of induced pluripotent stem cell derived hepatocytes. J. Hepatol. 65, 182-199. doi: 10.1016/j.jhep.2016.02.025

Hodges, V. M., Molloy, G. Y., and Wickramasinghe, S. N. (2001). Demonstration of mRNA for five species of cytochrome P450 in human bone marrow, bone marrow-derived macrophages and human haemopoietic cell lines. Br. J. Haematol. 180, 151-156. doi: 10.1046/j.1365-2141.2000.01816.x

Hoeffel, G., Chen, J., Lavin, Y., Low, D., Almeida, F. F., See, P., et al. (2015). C-Myb+ erythro-myeloid progenitor-derived fetal monocytes give rise to adult tissue-resident macrophages. Immunity 42, 665-678. doi: 10.1016/j.immuni.2015.03.011

Holt, M. P., Cheng, L., and Ju, C. (2008). Identification and characterization of infiltrating macrophages in acetaminophen-induced liver injury. J. Leukocyte Biol. 84, 1410-1421. doi: 10.1189/jlb.0308173

Honegger, P. (1999). Overview of cell and tissue culture techniques. Curr. Protoc. Pharmacol. 4, 12.11.11-12.11.12. doi: 10.1002/0471141755.ph1201s04

Hoofnagle, J. H., and Björnsson, E. S. (2019). Drug-induced liver injury-types and phenotypes. N. Eng. J. Med. 381, 264-273. doi: 10.1056/NEJMra1816149

Jaeschke, H. (2007). "Kupffer cells," in Textbook of Hepatology: From Basic Science to Clinical Practice, $3 r d E d n$, eds J. Rodés, J.-P. Benhamou, A. T. Blei, J. Reichen, and M. Rizzetto (Malden, MA: Blackwell Publishing Ltd), 36-42.

Jiang, J., Messner, S., Kelm, J., van Herwijnen, M., Jennen, D., Kleinjans, J., et al. (2019). Human 3D multicellular microtissues: an upgraded model for the in vitro mechanistic investigation of inflammation-associated drug toxicity. Toxicol. Lett. 312, 34-44. doi: 10.1016/j.toxlet.2019.05.004

Jones, E., and Summerfield, J. (1989). "Kupffer cells," in The Liver: Biology and Pathobiology, eds I. M. Arias, W. B. Jakoby, H. Popper, D. Schachter, and D. A. Shafritz (New York, NY: Raven Press, Ltd), 969.

Ju, C., Reilly, T. P., Bourdi, M., Radonovich, M. F., Brady, J. N., George, J. W., et al. (2002). Protective Role of Kupffer cells in acetaminophen-induced hepatic injury in mice. Chem. Res. Toxicol. 15, 1504-1513. doi: 10.1021/tx0255976

Kato, R., and Uetrecht, J. (2017). Supernatant from hepatocyte cultures with drugs that cause idiosyncratic liver injury activates macrophage inflammasomes. Chem. Res. Toxicol. 30, 1327-1332. doi: 10.1021/acs.chemrestox.7b00065

Kaur, G., and Dufour, J. M. (2012). Cell lines: valuable tools or useless artifacts. Spermatogenesis 2, 1-5 doi: 10.4161/spmg.19885

Kegel, V., Pfeiffer, E., Burkhardt, B., Liu, J. L., Zeilinger, K., Nüssler, A. K., et al. (2015). Subtoxic concentrations of hepatotoxic drugs lead to Kupffer cell activation in a human in vitro liver model: an approach to study DILI. Media. Inflamm. 2015:640631. doi: 10.1155/2015/640631

Kermanizadeh, A., Brown, D. M., Moritz, W., and Stone, V. (2019a). The importance of inter-individual Kupffer cell variability in the governance of hepatic toxicity in a 3D primary human liver microtissue model. Sci. Rep. 9, 1-9. doi: 10.1038/s41598-019-43870-8

Kermanizadeh, A., Brown, D. M., and Stone, V. (2019b). The variances in cytokine production profiles from non-or activated THP-1, Kupffer cell and human blood derived primary macrophages following exposure to either alcohol or a panel of engineered nanomaterials. PLOS ONE 14:e0220974. doi: 10.1371/journal.pone.0220974

Koop, D. R., Chernosky, A., and Brass, E. P. (1991). Identification and induction of cytochrome P450 2E1 in rat Kupffer cells. J. Pharmacol. Exp. Ther. 258, 1072-1076.

Kostadinova, R., Boess, F., Applegate, D., Suter, L., Weiser, T., Singer, T., et al. (2013). A long-term three dimensional liver co-culture system for improved prediction of clinically relevant drug-induced hepatotoxicity. Toxicol. Appl. Pharmacol. 268, 1-16. doi: 10.1016/j.taap.2013.01.012

Krenkel, O., Mossanen, J. C., and Tacke, F. (2014). Immune mechanisms in acetaminophen-induced acute liver failure. Hepatobiliary Surg.Nutr. 3:331-343. doi: 10.3978/j.issn.2304-3881.2014.11.01

Kuna, L., Bozic, I., Kizivat, T., Bojanic, K., Mrso, M., Kralj, E., et al. (2018). Models of drug induced liver injury (DILI)-current issues and future perspectives. Curr. Drug Metabol. 19, 830-838. doi: 10.2174/1389200219666180523 095355

Kurose, I., Miura, S., Higuchi, H., Watanabe, N., Kamegaya, Y., Takaishi, M., et al. (1996). Increased nitric oxide synthase activity as a cause of mitochondrial dysfunction in rat hepatocytes: roles for tumor necrosis factor $\alpha$. Hepatology 24, 1185-1192. doi: 10.1002/hep.510240534

Lauschke, V. M., Shafagh, R. Z., Hendriks, D. F., and Ingelman-Sundberg, M. (2019). 3D primary hepatocyte culture systems for analyses of liver diseases, drug metabolism, and toxicity: emerging culture paradigms and applications. Biotechnol. J. 14:1800347. doi: 10.1002/biot.201800347

Lavin, Y., Winter, D., Blecher-Gonen, R., David, E., Keren-Shaul, H., Merad, M., et al. (2014). Tissue-resident macrophage enhancer landscapes are shaped by the local microenvironment. Cell 159, 1312-1326. doi: 10.1016/j.cell.2014.11.018

Lee, C. Z., Kozaki, T., and Ginhoux, F. (2018). Studying tissue macrophages in vitro: are iPSC-derived cells the answer? Nat. Rev. Immunol. 18, 716-725. doi: 10.1038/s41577-018-0054-y

Lee, W. M., and Senior, J. R. (2005). Recognizing drug-induced liver injury: current problems, possible solutions. Toxicol. Pathol. 33, 155-164. doi: 10.1080/01926230590522356

Liaskou, E., Wilson, D. V., and Oo, Y. H. (2012). Innate immune cells in liver inflammation. Media. Inflamm. 2012:949157. doi: 10.1155/2012/949157

Lim, H. Y., Müller, N., Herold, M. J., Van Den Brandt, J., and Reichardt, H. M. (2007). Glucocorticoids exert opposing effects on macrophage function dependent on their concentration. Immunology 122, 47-53. doi: 10.1111/j.1365-2567.2007.02611.x

Liu, Z.-X., and Kaplowitz, N. (2002). Immune-mediated drug-induced liver disease. Clin. Liver Dis. 6, 755-774. doi: 10.1016/S1089-3261(02)00025-9

Liu, Z. X., Govindarajan, S., and Kaplowitz, N. (2004). Innate immune system plays a critical role in determining the progression and severity 
of acetaminophen hepatotoxicity. Gastroenterology 127, 1760-1774. doi: 10.1053/j.gastro.2004.08.053

Long, T. J., Cosgrove, P. A., Dunn, R. T., Stolz, D. B., Hamadeh, H., Afshari, C., et al. (2016). Modeling therapeutic antibody-small molecule drug-drug interactions using a three-dimensional perfusable human liver coculture platform. Drug Metab. Dispos. 44, 1940-1948. doi: 10.1124/dmd.116.071456

Ma, Y. Y., Yang, M. Q., He, Z. G., Wei, Q., and Li, J. Y. (2017). “The biological function of Kupffer cells in liver disease," in Biology of Myelomonocytic Cells, ed A. Ghosh (London: IntechOpen), 2. doi: 10.5772/67673

Maepa, S. W., and Ndlovu, H. (2020). Advances in generating liver cells from pluripotent stem cells as a tool for modelling liver diseases. Stem Cells 38, 606-612. doi: 10.1002/stem.3154

Mak, A., Kato, R., Weston, K., Hayes, A., and Uetrecht, J. (2018). Editor's highlight: an impaired immune tolerance animal model distinguishes the potential of troglitazone/pioglitazone and tolcapone/entacapone to cause IDILI. Toxicol. Sci. 161, 412-420. doi: 10.1093/toxsci/kfx219

Mak, A., and Uetrecht, J. (2017). Immune mechanisms of idiosyncratic drug-induced liver injury. J. Clin. Transl. Res. 3, 145-156. doi: 10.18053 /jctres.03.2017S1.001

March, S., Ramanan, V., Trehan, K., Ng, S., Galstian, A., Gural, N., et al. (2015). Micropatterned coculture of primary human hepatocytes and supportive cells for the study of hepatotropic pathogens. Nat. Protoc. 10:2027. doi: $10.1038 /$ nprot. 2015.128

Martin-Murphy, B. V., Holt, M. P., and Ju, C. (2010). The role of damage associated molecular pattern molecules in acetaminophen-induced liver injury in mice. Toxicol. Lett. 192, 387-394. doi: 10.1016/j.toxlet.2009.11.016

Martin-Murphy, B. V., Kominsky, D. J., Orlicky, D. J., Donohue, T. M. Jr., and Ju, C. (2013). Increased susceptibility of natural killer T-cell-deficient mice to acetaminophen-induced liver injury. Hepatology 57, 1575-1584. doi: $10.1002 /$ hep. 26134

Masson, M. J., Carpenter, L. D., Graf, M. L., and Pohl, L. R. (2008). Pathogenic role of natural killer $\mathrm{T}$ and natural killer cells in acetaminophen-induced liver injury in mice is dependent on the presence of dimethyl sulfoxide. Hepatology 48, 889-897. doi: $10.1002 /$ hep. 22400

McVay, M., Kanchagar, C., Khetani, S. R., and Ukairo, O. (2013). In vitro modeling of cytokine-drug interactions using micropatterned co-cultures of primary hepatocytes and Kupffer macrophages. Toxicol. Lett. 221:S150. doi: 10.1016/j.toxlet.2013.05.308

Medvec, A. R., Ecker, C., Kong, H., Winters, E. A., Glover, J., Varela-Rohena, A., et al. (2018). Improved expansion and in vivo function of patient $\mathrm{T}$ cells by a serum-free medium. Mol. Ther. Meth. Clin. D 8, 65-74. doi: 10.1016/j.omtm.2017.11.001

Melino, M., Gadd, V. L., Walker, G. V., Skoien, R., Barrie, H. D., Jothimani, D., et al. (2012). Macrophage secretory products induce an inflammatory phenotype in hepatocytes. World J. Gastroenterol. 18:1732. doi: 10.3748/wjg.v18.i15.1732

Messner, S., Agarkova, I., Moritz, W., and Kelm, J. (2013). Multi-cell type human liver microtissues for hepatotoxicity testing. Arch. Toxicol. 87, 209-213. doi: $10.1007 / \mathrm{s} 00204-012-0968-2$

Michael, S. L., Pumford, N. R., Mayeux, P. R., Niesman, M. R., and Hinson, J. A. (1999). Pretreatment of mice with macrophage inactivators decreases acetaminophen hepatotoxicity and the formation of reactive oxygen and nitrogen species. Hepatology 30, 186-195. doi: 10.1002/hep.5103 00104

Milosevic, N., Schawalder, H., and Maier, P. (1999). Kupffer cellmediated differential down-regulation of cytochrome P450 metabolism in rat hepatocytes. Eur. J. Pharmacol. 368, 75-87. doi: 10.1016/S0014-2999(98)00988-1

Mittal, N., Tasnim, F., Yue, C., Qu, Y., Phan, D., Choudhury, Y., et al. (2016). Substrate stiffness modulates the maturation of human pluripotent stem-cell-derived hepatocytes. ACS Biomate. Sci. Eng. 2, 1649-1657. doi: 10.1021/acsbiomaterials.6b00475

Monga, S. (2011). Molecular Pathology of Liver Diseases. New York, NY: Springer. doi: 10.1007/978-1-4419-7107-4

Moore, G. E., Gerner, R. E., and Franklin, H. A. (1967). Culture of normal human leukocytes. JAMA 199, 519-524. doi: 10.1001/jama.1967.03120080053007

Musson, R. A. (1983). Human serum induces maturation of human monocytes in vitro. Changes in cytolytic activity, intracellular lysosomal enzymes, and nonspecific esterase activity. Am. J. Pathol. 111:331.
Nelson, L. J., Treskes, P., Howie, A. F., Walker, S. W., Hayes, P. C., and Plevris, J. N. (2013). Profiling the impact of medium formulation on morphology and functionality of primary hepatocytes in vitro. Sci. Rep. 3:2735. doi: 10.1038/srep02735

Ng, W., Lobach, A. R., Zhu, X., Chen, X., Liu, F., Metushi, I. G., et al. (2012). Animal models of idiosyncratic drug reactions. Adv. Pharmacol. 63, 81-135. doi: 10.1016/B978-0-12-398339-8.00003-3

Nguyen, D. G., Funk, J., Robbins, J. B., Crogan-Grundy, C., Presnell, S. C., Singer, T., et al. (2016). Bioprinted 3D primary liver tissues allow assessment of organlevel response to clinical drug induced toxicity in vitro. PLOS ONE 11:e0158674. doi: 10.1371/journal.pone.0158674

Nguyen, T. V., Ukairo, O., Khetani, S. R., McVay, M., Kanchagar, C., Seghezzi, W., et al. (2015). Establishment of a hepatocyte-Kupffer cell coculture model for assessment of proinflammatory cytokine effects on metabolizing enzymes and drug transporters. Drug Metab. Dispos. 43, 774-785. doi: $10.1124 / \mathrm{dmd} .114 .061317$

Novik, E., Maguire, T. J., Chao, P., Cheng, K., and Yarmush, M. L. (2010). A microfluidic hepatic coculture platform for cell-based drug metabolism studies. Biochem. Pharmacol. 79, 1036-1044. doi: 10.1016/j.bcp.2009.11.010

Odegaard, J. I., Ricardo-Gonzalez, R. R., Red Eagle, A., Vats, D., Morel, C. R., Goforth, M. H., et al. (2008). Alternative (M2) activation of Kupffer cells by PPAR $\delta$ ameliorates obesity-induced insulin resistance. Cell Metab. 7, 496-507. doi: 10.1016/j.cmet.2008.04.003

Ogese, M. O., Faulkner, L., Jenkins, R. E., French, N. S., Copple, I. M., Antoine, D. J., et al. (2017). Characterization of drug-specific signaling between primary human hepatocytes and immune cells. Toxicol. Sci. 158, 76-89. doi: $10.1093 /$ toxsci/kfx069

Ogese, M. O., Jenkins, R. E., Adair, K., Tailor, A., Meng, X., Faulkner, L., et al. (2019). Exosomal transport of hepatocyte-derived drug-modified proteins to the immune system. Hepatology 70, 1732-1749. doi: 10.1002/hep.30701

Perdiguero, E. G., Klapproth, K., Schulz, C., Busch, K., Azzoni, E., Crozet, L., et al. (2015). Tissue-resident macrophages originate from yolk-sac-derived erythro-myeloid progenitors. Nature 518, 547-551. doi: 10.1038/nature13989

Poulsen, K. L., Albee, R. P., Ganey, P. E., and Roth, R. A. (2014). Trovafloxacin potentiation of lipopolysaccharide-induced tumor necrosis factor release from RAW 264.7 cells requires extracellular signal-regulated kinase and c-Jun N-terminal kinase. J. Pharmacol. Exp. Ther. 349, 185-191. doi: 10.1124/jpet.113.211276

Rennert, K., Otto, P., Funke, H., Huber, O., Tomaso, H., and Mosig, A. S. (2016). A human macrophage - hepatocyte co-culture model for comparative studies of infection and replication of Francisella tularensis LVS strain and subspecies holarctica and mediasiatica. BMC Microbiol. 16:2. doi: $10.1186 / \mathrm{s} 12866-015-0621-3$

Richert, L., Liguori, M. J., Abadie, C., Heyd, B., Mantion, G., Halkic, N., et al. (2006). Gene expression in human hepatocytes in suspension after isolation is similar to the liver of origin, is not affected by hepatocyte cold storage and cryopreservation, but is strongly changed after hepatocyte plating. Drug Metab. Dispos. 34, 870-879. doi: 10.1124/dmd.105.007708

Rose, K. A., Holman, N. S., Green, A. M., Andersen, M. E., and LeCluyse, E. L. (2016). Co-culture of hepatocytes and Kupffer cells as an in vitro model of inflammation and drug-induced hepatotoxicity. J. Pharm. Sci. 105, 950-964. doi: 10.1016/S0022-3549(15)00192-6

Saab, L. (2013). Development of a cellular predictive model of inflammation associated idiosyncratic drug-induced hepatotoxicity and investigation of its underlying cellular and molecular mechanisms (Doctoral dissertation). Strasbourg: Université de Strasbourg.

Sana, G., Lombard, C., Vosters, O., Jazouli, N., Andre, F., Stephenne, X., et al. (2014). Adult human hepatocytes promote CD4+ T-cell hyporesponsiveness via interleukin-10-producing allogeneic dendritic cells. Cell Transplant. 23, 1127-1142. doi: 10.3727/096368913X666421

Sarkar, U., Ravindra, K. C., Large, E., Young, C. L., Rivera-Burgos, D., Yu, J., et al. (2017). Integrated assessment of diclofenac biotransformation, pharmacokinetics, and omics-based toxicity in a three-dimensional human liver-immunocompetent coculture system. Drug Metab. Dispos. 45, 855-866. doi: $10.1124 / \mathrm{dmd} .116 .074005$

Selvaraj, S., Oh, J.-H., and Borlak, J. (2020). An adverse outcome pathway for immune-mediated and allergic hepatitis: a case study with the NSAID diclofenac. Arch. Toxicol. 94, 2733-2748. doi: 10.1007/s00204-020-02767-6 
Shan, Z., and Ju, C. (2019). Hepatic macrophages in drug-induced liver injury. Liver Res. 3, 170-175. doi: 10.1016/j.livres.2019.11.002

Shaw, P. J., Ganey, P. E., and Roth, R. A. (2010). Idiosyncratic drug-induced liver injury and the role of inflammatory stress with an emphasis on an animal model of trovafloxacin hepatotoxicity. Toxicol. Sci. 118, 7-18. doi: $10.1093 /$ toxsci/kfq168

Shaw, P. J., Hopfensperger, M. J., Ganey, P. E., and Roth, R. A. (2007). Lipopolysaccharide and trovafloxacin coexposure in mice causes idiosyncrasylike liver injury dependent on tumor necrosis factor-alpha. Toxicol. Sci. 100, 259-266. doi: 10.1093/toxsci/kfm218

Shenton, J. M., Chen, J., and Uetrecht, J. P. (2004). Animal models of idiosyncratic drug reactions. Chem. Biol. 150, 53-70. doi: 10.1016/j.cbi.2004.09.001

Shi, Y., Inoue, H., Wu, J. C., and Yamanaka, S. (2017). Induced pluripotent stem cell technology: a decade of progress. Nat. Rev. Drug Discov. 16:115. doi: 10.1038/nrd.2016.245

Stoddart, M. J., Richards, R., and Alini, M. (2012). In vitro experiments with primary mammalian cells: to pool or not to pool. Eur. Cell Mater. 24, i-ii. doi: 10.22203/eCM.v024a00

Sunman, J. A., Hawke, R. L., LeCluyse, E. L., and Kashuba, A. D. (2004). Kupffer cell-mediated IL-2 suppression of CYP3A activity in human hepatocytes. Drug Metab. Dispos. 32, 359-363. doi: 10.1124/dmd.32.3.359

Swales, N. J., Johnson, T., and Caldwell, J. (1996a). Cryopreservation of rat and mouse hepatocytes. II. Assessment of metabolic capacity using testosterone metabolism. Drug Metab. Dispos. 24, 1224-1230.

Swales, N. J., Luong, C., and Caldwell, J. (1996b). Cryopreservation of rat and mouse hepatocytes. I. Comparative viability studies. Drug Metab. Dispos. 24, 1218-1223.

Takata, K., Kozaki, T., Lee, C. Z. W., Thion, M. S., Otsuka, M., Lim, S., et al. (2017). Induced-pluripotent-stem-cell-derived primitive macrophages provide a platform for modeling tissue-resident macrophage differentiation and function. Immunity 47, 183-198.e186. doi: 10.1016/j.immuni.2017.06.017

Tasnim, F., Phan, D., Toh, Y.-C., and Yu, H. (2015). Cost-effective differentiation of hepatocyte-like cells from human pluripotent stem cells using small molecules. Biomaterials 70, 115-125. doi: 10.1016/j.biomaterials.2015.08.002

Tasnim, F., Toh, Y.-C., Qu, Y., Li, H., Phan, D., Narmada, B. C., et al. (2016). Functionally enhanced human stem cell derived hepatocytes in galactosylated cellulosic sponges for hepatotoxicity testing. Mol. Pharm. 13, 1947-1957. doi: 10.1021/acs.molpharmaceut.6b00119

Tasnim, F., Xing, J., Huang, X., Mo, S., Wei, X., Tan, M.-H., et al. (2019). Generation of mature Kupffer cells from human induced pluripotent stem cells. Biomaterials 192, 377-391. doi: 10.1016/j.biomaterials.2018.11.016

Taylor, M. E., Snelling, T., Smith, D. F., and Drickamer, K. (2019). Absence of a human ortholog of rodent Kupffer cell galactose-binding receptor encoded by the CLEC4f gene. Glycobiology 29, 332-345. doi: 10.1093/glycob/ cwyl13

Thurman, R. G., Bradford, B. U., Iimuro, Y., Knecht, K. T., Arteel, G. E., Yin, M., et al. (1998). The role of gut-derived bacterial toxins and free radicals in alcohol-induced liver injury. J. Gastroenterol. Hepatol. 13, S39-S50. doi: 10.1111/jgh.1998.13.s1.39

Triantafyllou, E., Pop, O. T., Possamai, L. A., Wilhelm, A., Liaskou, E., Singanayagam, A., et al. (2018). MerTK expressing hepatic macrophages promote the resolution of inflammation in acute liver failure. Gut 67, 333-347. doi: 10.1136/gutjnl-2016-313615
Trump, L. R., Nayak, R. C., Singh, A. K., Emberesh, S., Wellendorf, A. M., Lutzko, C. M., et al. (2019). Neutrophils derived from genetically modified human induced pluripotent stem cells circulate and phagocytose bacteria in vivo. Stem Cell Trans. Med. 8, 557-567. doi: 10.1002/sctm.18-0255

Tukov, F. F., Maddox, J. F., Amacher, D. E., Bobrowski, W. F., Roth, R. A., and Ganey, P. E. (2006). Modeling inflammation-drug interactions in vitro: a rat Kupffer cell-hepatocyte coculture system. Toxicol. In Vitro 20, 1488-1499. doi: 10.1016/j.tiv.2006.04.005

Uetrecht, J. (2019). Mechanistic studies of idiosyncratic DILI: clinical implications. Front. Pharmacol. 10:837. doi: 10.3389/fphar.2019.00837

van de Laar, L., Saelens, W., De Prijck, S., Martens, L., Scott, C. L., Van Isterdael, G., et al. (2016). Yolk sac macrophages, fetal liver, and adult monocytes can colonize an empty niche and develop into functional tissue-resident macrophages. Immunity 44, 755-768. doi: 10.1016/j.immuni.2016.02.017

Volpato, V., and Webber, C. (2020). Addressing variability in iPSC-derived models of human disease: guidelines to promote reproducibility. Dis. Model Mech. 13:dmm042317. doi: 10.1242/dmm.042317

Waddington, J. C., Meng, X., Naisbitt, D. J., and Park, B. K. (2018). Immune drug-induced liver disease and drugs. Curr. Opin. Toxicol. 10, 46-53. doi: 10.1016/j.cotox.2017.12.006

Werb, Z. (1978). Biochemical actions of glucocorticoids on macrophages in culture. Specific inhibition of elastase, collagenase, and plasminogen activator secretion and effects on other metabolic functions. J. Exp. Med. 147, 1695-1712. doi: $10.1084 /$ jem.147.6.1695

Wewering, F., Jouy, F., Wissenbach, D. K., Gebauer, S., Blüher, M., Gebhardt, R., et al. (2017). Characterization of chemical-induced sterile inflammation in vitro: application of the model compound ketoconazole in a human hepatic co-culture system. Arch. Toxicol. 91, 799-810. doi: 10.1007/s00204-016-1686-y

Yang, W., Tao, Y., Wu, Y., Zhao, X., Ye, W., Zhao, D., et al. (2019). Neutrophils promote the development of reparative macrophages mediated by ROS to orchestrate liver repair. Nat. Commun. 10, 1-14. doi: 10.1038/s41467-019-09046-8

Yin, C., Evason, K. J., Asahina, K., and Stainier, D. Y. (2013). Hepatic stellate cells in liver development, regeneration, and cancer. J. Clin. Invest. 123, 1902-1910. doi: 10.1172/JCI66369

Zeilinger, K., Freyer, N., Damm, G., Seehofer, D., and Knöspel, F. (2016). Cell sources for in vitro human liver cell culture models. Exp. Biol. Med. 241, 1684-1698. doi: 10.1177/1535370216657448

Zinchenko, Y. S., Schrum, L. W., Clemens, M., and Coger, R. N. (2006). Hepatocyte and Kupffer cells co-cultured on micropatterned surfaces to optimize hepatocyte function. Tissue Eng. 12, 751-761. doi: 10.1089/ten.2006.12.751

Conflict of Interest: The authors declare that the research was conducted in the absence of any commercial or financial relationships that could be construed as a potential conflict of interest.

Copyright $\odot 2021$ Tasnim, Huang, Lee, Ginhoux and Yu. This is an open-access article distributed under the terms of the Creative Commons Attribution License (CC $B Y)$. The use, distribution or reproduction in other forums is permitted, provided the original author(s) and the copyright owner(s) are credited and that the original publication in this journal is cited, in accordance with accepted academic practice. No use, distribution or reproduction is permitted which does not comply with these terms. 